\title{
SIKAP PELANGGAN MILLENNIAL INDONESIA TERHADAP IKLAN ONLINE
}

\author{
Elvani Marcelin P. ${ }^{1}$, Marry ${ }^{2}$, Marvin Anggasta ${ }^{3}$, M. Fandhi Al-Barru ${ }^{4}$, Prisa Ngadianto ${ }^{5}$ \\ prisa.ngadianto25@gmail.com,email_fandhi@yahoo.com,marvin.anggasta@gmail.com, \\ fann.merry@gmail.com, pontoan.elvani@gmail.com
}

\section{Program MM Sekolah Bisnis dan Ekonomi Universitas Prasetiya Mulya}

\begin{abstract}
:
The number of Internet users in Indonesia are increasing rapidly, especially among Millennial Generation. Nowadays, almost all the transactions can be done through online. The main purpose is to understand Indonesia millennial customer attitude towards online advertising, Thus, give the marketers knowledge for effective strategy for publishing online advertising. Conceptual framework designed with five independent variable hypotheses: entertainment, informativeness, irritation, credibility, and incentives, which might affect millennial user attitudes towards online advertising. The result of this research which conducted among 209 respondents: Informativeness, entertainment and credibility have shown a direct positive and significant impact on consumer attitudes toward online advertising.
\end{abstract}

\begin{abstract}
Abstrak:
Jumlah pengguna internet di Indonesia semakin meningkat pesat, terutama di kalangan Generasi Millennial. Sekarang ini, hampir semua transaksi dapat dilakukan melalui online. Tujuan utamanya adalah untuk memahami sikap pelanggan Millennial Indonesia terhadap iklan online. Dengan demikian, memberikan pengetahuan kepada pemasar mengenai strategi yang efektif dalam mempublikasikan iklan online. Kerangka kerja konseptual yang dirancang dengan lima hipotesis variabel independen: entertainment, informativeness, irritation, credibility, dan incentives, yang diduga mempengaruhi sikap pengguna Millennial terhadap iklan online. Hasil penelitian yang dilakukan di antara 209 responden: Informativeness, entertainment dan credibility telah menunjukkan dampak secara langsung yaitu positif dan signifikan terhadap sikap konsumen terhadap periklanan online.
\end{abstract}

Keywords: Iklan Online Advestising, Millennial, Attitude, Indonesia.

\section{PENDAHULUAN}

Penggunaan search engine perangkat seluler maupun penelusuran melalui perangkat digital lainnya berkembang pesat dalam beberapa tahun terakhir mengikuti peningkatan penetrasi internet di seluruh dunia. Peningkatan penetrasi internet ini memberikan dampak dan perubahan signifikan dalam berbagai aspek kehidupan sosial masyarakat. Berdasarkan data dari Asosiasi Penyelenggara Jasa Internet Indonesia tahun 2016, jumlah pengguna internet Indonesia hingga tahun 2016 adalah 132,7 juta pengguna atau sekitar 51,5\% dari total jumlah penduduk Indonesia sebesar 256,2 juta, dan bila dibandingkan pada tahun 2014 sebesar 88,1 
juta pengguna, terjadi kenaikan sebesar 44,6 juta atau sebesar $50.6 \%$ dalam kurun waktu 2 tahun (2014-2016). Tentunya hal ini menjadi peluang, terutama bagi para pengusaha untuk memaksimalkan penjualan produk atau layanan dengan menggunakan iklan online.

Studi sikap pelanggan terhadap iklan online menjadi fokus perhatian dalam sejumlah kajian di bidang komunikasi pemasaran. Kajian-kajian awal menunjukkan bahwa pelanggan pada awalnya cenderung menyikapi iklan di media massa (print adv dan TVC) secara positif, namun dalam perkembangannya mulai terjadi perubahan. Pada saat yang sama, pertumbuhan internet dan iklan online yang ditawarkan sebagai konten media baru justru disikapi secara positif (Schlosser et al.,1999). Penyikapan positif terhadap iklan online ini disebabkan karena iklan online mampu menyampaikan informasi dalam format audio visual dan interaktif sehingga pesan komersial yang disampaikan tidak hanya dianggap informatif melainkan juga menghibur (Tsang et al., 2004). Maka dapat ditarik kesimpulan bahwa setiap pelanggan memiliki advertising values yang berbeda antara iklan yang ditampilkan dalam media massa dan online. Advertising values terhadap iklan diduga dapat mempengaruhi sikap pelanggan mereka terkait produk yang ditawarkan dalam iklan tersebut.

Era digitalisasi bukan hanya mengubah cara pandang pemasaran dalam konteks jalur komunikasi. Era digital mengubah karakter dan perilaku konsumen yang lahir dan bertumbuh di era ini. Generasi Millennial memiliki selera dan perilaku yang berbeda dalam pembelian dan cara mereka mengkonsumsi produk atau layanan yang tersedia. Pengaruh terbesar digital pada perilaku adalah searching cost sebuah produk menjadi murah. Adapun berdasarkan laporan Goldman Sachs mengambil hasil survei AIMIA inc, sebanyak 57\% Millennial membandingkan harga. Generasi Millennial menjadi target ideal untuk dunia digital marketing.

Perusahaan melalui sarana pemasaran seluler ini dapat membuat orang membaca pesan promosi mereka (Scharl et al., 2005) ${ }^{[1]}$. Studi sikap pelanggan terhadap iklan online dilakukan di banyak negara, namun terdapat keterbatasan untuk penelitian serupa di Indonesia, khususnya untuk generasi Millennial yang merupakan target ideal di era digitalisasi ini. Ducoffe (1996) mengusulkan faktor-faktor yang dirasakan: informativeness, entertainment dan irritation sebagai anteseden nilai dari periklanan, yang pada gilirannya memiliki hubungan positif dengan sikap pelanggan terhadap iklan web. Brackett dan Carr (2001) ${ }^{[10]}$ mengajukan credibility sebagai faktor keempat nilai periklanan internet, dan menemukan efek langsung antara tiga pendahulunya. Insentive merupakan penggunaan alat motivasi seperti diskon, kupon, kompetisi, harga khusus yang ditawarkan untuk meningkatkan produktifitas penjualan barang dan layanan sehingga cenderung menghasut pelanggan untuk melakukan pembelian. Dari hal tersebut dan beberapa kajian yang telah ada, peneliti menambahkan insentive sebagai faktor kelima dalam iklan online yang mempengaruhi sikap pelanggan.

Tujuan utama penelitian untuk memahami faktor-faktor yang mempengaruhi efektifitas iklan online terhadap pelanggan Millennial di Indonesia. Peneliti mencoba mencari tahu sikap pelanggan berdasarkan beberapa faktor, yaitu: entertainment, informativeness, irritation, credibility, dan incentive. Sehingga para pemasar dapat mengetahui skenario yang tepat untuk memasang iklan online agar tepat sasaran. Dengan demikian, penelitian ini mampu membantu pengambilan keputusan bisnis yang tepat dan membuat strategi kompetitif yang cocok 
mengenai komunikasi bisnis dan iklan yang efektif dalam rangka menjamin pengembangan ekonomi berkelanjutan dalam persaingan bisnis yang kompetitif di Indonesia.

\section{TINJAUAN PUSTAKA DAN PENGEMBANGAN HIPOTESA}

\section{Attitude}

Kotler (2010) menyatakan bahwa sikap seseorang mendefinisikan penilaiannya yang menguntungkan atau tidak menguntungkan, ekspresif perasaan dan beragam tindakan predisposisi terhadap beberapa objek atau gagasan Sikap adalah pre-disposisi yang dipelajari berperilaku secara konsisten baik atau tidak menguntungkan sehubungan dengan tujuan tertentu (Schiffman et al., 2008). Keyakinan dan sikap konsumen terhadap iklan merupakan indikator penting efektivitas periklanan (Mehta, 2000).

\section{Millennial}

Generasi Millennial dideskripsikan sebagai kelompok generasi yang lahir diantara tahun 1980 dan 2000 (Goldman Sachs Global Investment Research, 2017). Demografi global selalu memainkan peran penting dalam pertumbuhan ekonomi. Sekarang ini merupakan masa dimana Generasi Millennial sebagai mayoritas telah memasuki dunia kerja. Pendapatan mereka yang tergolong tinggi dan tumbuh dengan cepat menentukan keinginan karakteristik generasi sekarang maupun masa yang akan datang, sehingga semakin mempengaruhi bisnis dan pasar ekonomi.

Generasi ini juga diproyeksikan akan memiliki persentase jumlah sebesar 39\% atau sebesar 110 juta jiwa dari total proyeksi jumlah penduduk Indonesia sebesar 285 juta jiwa di tahun 2025 (BPS, 2013). Dari beberapa penelitian dan artikel yang sudah ada, penelitian ini menggunakan Generasi Millennial sebagai subyek penelitian karena Generasi Millennial memiliki jumlah terbanyak pada zaman ini, serta sangat menguasai penggunaan internet.

Generasi ini juga diyakini akan sangat berpengaruh dalam menentukan tren penggunaan produk dan layanan di masa depan, khususnya sejak memasuki era digital. Dengan adanya teknologi digital, Millennial pun sangat aktif menggunakan media sosial dan media online untuk berinteraksi dengan brand pilihan mereka. Selain itu Millennial juga banyak menggunakan tekonologi untuk interaksi sosialnya, sebagai contoh berdasarkan laporan Christin Barton, Jeff Fromm dan Chris Egan (2012) dari Boston Consulting Group, 79\% millennial di Amerika Serikat menggunakan platform sosial media dan $47 \%$ dari mereka menjaga hubungan baik dan mendapatkan lebih banyak koneksi dari sosial media. Dari hasil survei di negara berkembang, 83\% dari generasi Millennial tidak akan tertarik menggunakan produk dan layanan jika para penyedia tidak mampu memberikan pengalaman terbaik bagi mereka.

\section{Iklan Online}

Dunia pemasaran sekarang ini telah memasuki era baru yang dapat dikatakan cukup ekstrim. Efektifitas pemasaran dengan metode iklan tradisional mulai mengalami penurunan dan metode baru yang dikenal sebagai "pemasaran digital" mengalami perkembangan secara signifikan. Pemasaran digital yang menggabungkan faktor-faktor psikologis, teknologis, dan humanis ini dianggap lebih interaktif dibandingkan iklan yang dipajang di media surat kabar 
atau koran. Adapun online advertising adalah metode pemasaran dengan menggunakan internet dengan tujuan menyampaikan pesan pemasaran (promosi) untuk menarik pelanggan. Iklan online yang disampaikan melalui internet ataupun gadget meliputi beberapa teknik seperti iklan pada halaman mesin pencari, iklan banner, periklanan yang melibatkan media interakttif digital seperti audio dan video streaming, e-mail marketing, termasuk iklan yang masuk pada $e$ mail spam. Iklan online ditempatkan di email dan di jaringan sosial, dan cara-cara lain di mana pengiklan menggunakan internet. Tentu saja, ini tidak hanya terbatas pada komputer, iklan digital dapat ditemukan di manapun ketika mengakses web, misalnya melalui perangkat mobile.

\section{Company's Attitude Towards Online Advertising}

Beberapa konsultan internet advertising berpendapat bahwa terdapat beberapa keuntungan sebuah perusahaan ketika berpromosi dengan iklan online, diantaranya menerbitkan informasi dan konten dengan efektif dan efisien. Online advertising membuat perusahaan lebih mudah dan lebih cepat dalam memasarkan produk dan jasanya, serta tidak membatasi cakupan wilayah dan waktu.

Korporat dapat berinteraksi dengan pelanggan dengan mudah karena konsumen diizinkan mengumpulkan informasi, berpartisipasi dalam desain produk, mengeksplorasi promosi, mengatur pengiriman, penjualan dan menerima dukungan pasca pembelian (Pavlou dan Stewart, 2000). Selain itu, melalui internet, korporat juga mampu menyampaikan pesan iklan dengan cara yang lebih kreatif. Misalnya, pesan iklan yang muncul di internet dengan animasi yang menarik, bukan sekadar kata-kata membuat lebih mudah untuk menarik perhatian konsumen (Tsang dan Tse, 2005). Ini akan mendorong konsumen dan memungkinkan mereka menikmati iklan dibandingkan dengan iklan yang berada outlet tradisional. Hal ini dapat membantu korporat dalam meningkatkan pemahaman mereka terhadap konsumen, dan dengan demikian menghasilkan dan mengelola hubungan dekat dengan klien mereka (Abd Aziz et al., 2008).

Luasnya jangkauan internet membuat iklan online dapat membantu perusahaan memasarkan produk dan jasanya ke seluruh dunia dengan biaya yang kompetitif di pasaran, dimana perusahaan tidak perlu memasang billboard untuk produknya di semua tempat di dunia (Clark Gates Gorge, 2013). Selain daripada menarik lebih banyak pelanggan dan mengelola hubungan jangka panjang, iklan online juga merupakan media marketing yang sangat efisien. Berdasarkan data Wikiinvest di tahun 2006, standar biaya iklan atau Cost per Thousand Impression (CPM) dari iklan online adalah yang termurah dibandingkan media lain, disebutkan iklan online hanya menghabiskan biaya \$6 untuk setiap seribu kesan dari konsumen. Dengan efektifitas dan efisiensinya, maka ikan online akan selalu menjadi media alternatif yang disukai oleh perusahaan.

\section{Customer's Attitude towards Online Advertising}

Sikap konsumen dapat didefinisikan sebagai refleksi langsung manusia terhadap iklan online (Bauer \& Greyser, 1968). Sikap konsumen mencakup perilaku, perasaan, dan persepsi. Perilaku adalah tindakan atau reaksi individu dalam menanggapi rangsangan eksternal atau internal (Keller, 1993). Merasa adalah keadaan emosional seseorang seperti sukacita, 
kegembiraan, dan ketidaksenangan. Persepsi adalah tindakan yang dirasakan oleh individu melalui melihat, mendengar, mencium atau menyentuh (Keller, 1993).

Sikap konsumen dipengaruhi oleh beberapa faktor, seperti entertainment, informativeness, irritation, credibility, dan insentive. Entertainment adalah pola pikir individu terhadap iklan online yang menyenangkan dan mengasyikkan (O'Shaughnessy dan Jackson O'Shaughnessy, 2002) Informativeness adalah persepsi konsumen apakah iklan online adalah sumber berharga yang memberi nilai tambah terhadap merek dan informasi terkini di pasar (Ducoffe, 1996). Irritation adalah gambaran ketika konsumen merasa terganggu oleh taktik iklan mereka yang menyebalkan, menyinggung atau terlalu manipulatif (Ducoffe, 1996). Credibility adalah persepsi konsumen terhadap tingkat kepercayaan dan keyakinan sebuah iklan online (MacKenzie dan Lutz, 1989). Insentive didefinisikan sebagai pertimbangan perolehan material sebagai aspek penting kehidupan, mengejar kebahagiaan, dan jumlah harta benda sebagai korelasi menuju kesuksesan dalam hidup (Richins and Dawson, 1992).

Entertainment, informativeness, irritation, credibility, dan insentive adalah faktor penting dalam penelitian ini karena kelima faktor ini adalah variabel yang ditetapkan pada penelitian dan sering kali digunakan peneliti lain dalam topik penelitian mereka yang serupa dengan penelitian ini. Kelima faktor ini menunjukkan hubungan kuat dengan sikap konsumen terhadap iklan online.

Sikap konsumen untuk sebuah iklan memiliki kontrol penting terhadap efektivitas periklanan, niat membeli dan sikap merek (MacKenzie \& Lutz, 1989). Penelitian menggunakan Teori Reasoned Action (Scharl et al., 2005). Jika pengiklan mobile dapat menyajikan kredibilitas dan hiburan dalam iklan mereka, konsumen bersedia untuk melihat iklan dan terpengaruh untuk membeli produk dan layanan.

\section{Conceptual Research Framework}

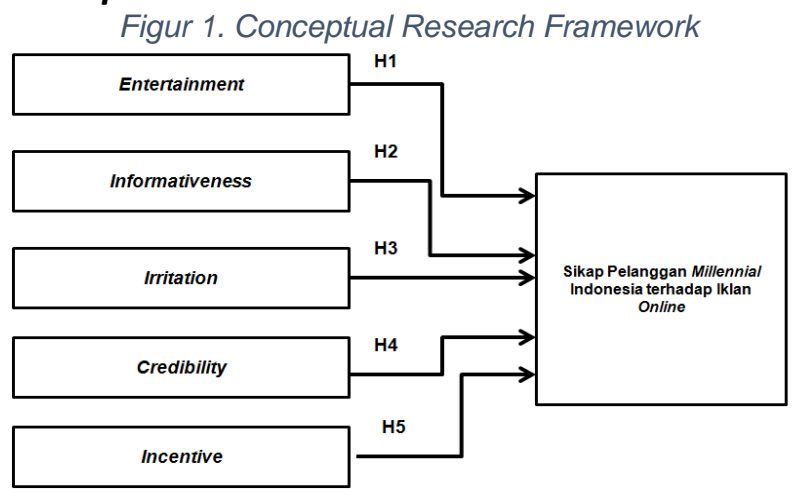

Independent Variables
Penelitian ini mengembangkan kerangka kerja konseptual atas Sikap Pelanggan Millennial terhadap Iklan Online. Figur di samping memiliki hipotesa 5 variabel independen, yaitu entertainments, informativenes, irritation, credibility dan incentives yang berpengaruh terhadap Sikap Pelanggan Millennial terhadap Iklan Online di Indonesia.

\section{PENGEMBANGAN HIPOTESA}

\section{Entertainment}

Entertainment dapat didefinisikan sebagai kemampuan dalam memenuhi kebutuhan masyarakat untuk pelarian, pengalihan perhatian, kenikmatan estetis, atau kenikmatan emosional. Unsur entertainment dalam periklanan dapat memenuhi kebutuhankonsumen akan kenikmatan estetis dan pelepasan emosi (Ducoffe, 1996) ${ }^{[9]}$. Ponsel kini telah menjadi media 
dan entertainment platform yang menonjol. Layanan entertainment dapat memberi nilai tambah bagi pelanggan dan meningkatkan loyalitas pelanggan (Haghirian \& Dickinger, 2004) ${ }^{[12]}$. Berdasarkan uraian di atas maka dapat dirumuskan hipotesis penelitian ini sebagai berikut:

H1: Faktor "entertainment" dari sebuah iklan online memiliki suatu pengaruh positif yang signifikan terhadap sikap pelanggan Millennial di Indonesia.

\section{Informativeness}

Informativeness diintepretasikan sebagai kemampuan periklanan untuk menyampaikan informasi kepada pelanggan guna memenuhi kebutuhannya. Teori Tingkat Stimulasi Optimum menyatakan bahwa orang bercita-cita untuk mencapai tingkat stimulasi tertentu dan mengumpulkan informasi dengan motivasi intrinsik (Hoffman, 1996). Informativeness mempengaruhi sikap konsumen terhadap iklan online pada umumnya sehingga dapat disimpulkan bahwa informativeness pesan iklan online berpengaruh positif terhadap perilaku (Abdul Azeem dan Zia ulHaq (2012) ${ }^{[19]}$. Salah satu tujuan periklanan yaitu dengan memberi informasi ke konsumen tentang suatu produk atau fitur baru dari produk yang ada, juga membuat konsumen sadar akan perubahan harga produk (Kotler \& Keller, 2006) ${ }^{[20]}$. Atas uraian tersebut maka dapat dirumuskan hipotesis penelitian ini sebagai berikut :

H2: Faktor "informativeness" dari sebuah iklan online memiliki suatu pengaruh positif yang signifikan terhadap sikap pelanggan Millennial di Indonesia.

\section{Irritation}

Dalam lingkungan tradisional, ketika iklan mengganggu, menyinggung, menghina atau memanipulasi konsumen, iklan mungkin dianggap sebagai ancaman terhadap kebebasan dan persepsi ini memiliki efek negatif pada nilai iklan (Ducoffe, 1995) ${ }^{\text {[21] }}$. Exploitasi iklan online terhadap pengguna internet menyebabkan timbulnya rasa terganggu kepada pengguna internet (Kim and Sundar, 2010; Tassi, 2013, Jurnal Attitudes toward Mobile Search ads A study among Mexicans). Dengan demikian maka dapat dirumuskan hipotesis penelitian ini sebagai berikut :

H3: Faktor "irritation" dari sebuah iklan online memiliki pengaruh negatif yang signifikan terhadap sikap pelanggan Millennial di Indonesia.

\section{Credibility}

Konsep kredibilitas telah mendapat banyak perhatian sejak akhir 1990-an ketika internet mulai menyediakan lingkungan interaksi informasi baru yang memungkinkan pengguna mencari informasi dan berkomunikasinya dengan orang lain dengan suatu cara yang belum pernah dilakukan. Sebagai konsekuensinya, para peneliti dan praktisi di berbagai bidang termasuk ilmu informasi, pemasaran, sistem informasi manajemen, studi komunikasi dan psikologi telah memeriksa kredibilitas dari berbagai perspektif yang berbeda (Rieh \& Danielson, 2007). MacKenzie dan Lutz $(1989)^{[6]}$, mendefinisikan kredibilitas iklan sebagai persepsi konsumen tentang kejujuran dan kepercayaan iklan secara umum. Konsep dan pengukuran kredibilitas 
iklan menunjukkan bahwa konsep tersebut mengacu pada kepercayaan konsumen secara umum terhadap integritas periklanan. Kredibilitas sebuah iklan dipengaruhi oleh berbagai faktor, terutama oleh kredibilitas perusahaan (Goldsmith et al., 2000) ${ }^{[22]}$. Penelitian yang dilakukan oleh berbagai peneliti telah mengidentifikasi bahwa ada korelasi positif antara persepsi konsumen tentang kredibilitas iklan dan sikap konsumen terhadap iklan. (Brackett, 2001) ${ }^{[23]}$. Atas uraian tersebut, maka dapat dirumuskan hipotesis penelitian ini sebagai berikut:

H4: Faktor "credibility" dari sebuah iklan online memiliki suatu pengaruh positif yang signifikan terhadap sikap pelanggan Millennial di Indonesia.

\section{Incentive}

Incentive adalah hadiah tambahan yang berfungsi sebagai alat motivasi untuk tindakan atau perilaku yang diinginkan. Periklanan berbasis incentive memberi imbalan finansial dalam bentuk tertentu kepada individu yang setuju untuk menerima promosi dan campaign. Imbalan disini termasuk penggunaan alat motivasi seperti diskon, kupon, kompetisi, permainan, premi, harga khusus, dalam rangka mempromosikan penjualan produk dan layanan. Contohnya, perusahaan transportasi online memberikan potongan tarif apabila menggunakan kode promo yang diberikan. Harsono (2004) mengemukakan bahwa insentif adalah suatu sistem kompensasi yang menyesuaikan pemberian atas hasil yang dicapai, sehingga memicu pekerja untuk menghasilkan sesuatu secara maksimal. Cascio (1995) menyampaikan "Sebuah insentif adalah suatu penghargaan yang bervariasi, bagi setiap individu dalam kelompok, yang mengetahui perbedaan dalam mencapai suatu hasil. Mereka dirancang untuk merangsang atau memotivasi usaha yang lebih besar terhadap produktivitas". Maka dapat dirumuskan hipotesa penelitian sebagai berikut:

H5: Faktor "incentive" dari sebuah iklan online memiliki suatu pengaruh positif yang signifikan terhadap sikap pelanggan Millennial di Indonesia.

\section{METODOLOGI PENELITIAN}

Metode penelitian yang digunakan dalam penelitian ini adalah survei. Pemilihan survei sebagai metode penelitian dalam riset ini didasarkan pada pertimbangan bahwa survei memiliki kapabilitas untuk mengumpulkan dan menganalisis data secara detail, terstruktur, dan memperoleh informasi dari responden dalam jumlah yang besar (Berger, 2000; De Vaus, 1991). Selain itu, penelitian survei dapat digunakan pula untuk mengetahui sikap, perasaan, prasangka, keyakinan, dan nilai-nilai yang dimiliki oleh responden (Prajarto, 2010).

Populasi dalam penelitian ini adalah seluruh pengguna internet termasuk mobile user di Indonesia. Kuisioner didistribusikan langsung ke responden di beberapa pulau di Indonesia sebagai sample penelitian. Dalam penelitian ini, peneliti mendistribusikan 209 kuisioner untuk pengukuran sikap pelanggan terhadap online advertising. Kuisioner survei tersebut meliputi 21 pertanyaan pengukuran sikap pelanggan, termasuk beberapa pertanyaan demografis, usia, dan pendapatann pelanggan untuk pemahaman hasil belajar yang lebih baik. Adapun survei ini menggunakan 7 (tujuh) poin skala diferensial semantik yang digunakan untuk mendesain sikap responden. Dimana 1 = sangat tidak setuju, 2 = tidak setuju, $3=$ cukup tidak setuju, $4=$ netral, 5 = cukup setuju, 6 = setuju, 7 = sangat setuju. Data sekunder yang merupakan sumber data 
penelitian yang diperoleh peneliti secara tidak langsung melalui media perantara, dalam hal ini diperoleh dari artikel dan publikasi terkait lainnya.

Tabel 1. Data Demografi

\begin{tabular}{|c|c|c|c|}
\hline Demografi & Variabel & Frekuensi & Persentase \\
\hline \multirow{2}{*}{ Usia } & $17-27$ tahun & 99 & $47 \%$ \\
\hline & $28-37$ tahun & 110 & $53 \%$ \\
\hline \multirow{2}{*}{ Jenis Kelamin } & Pria & 98 & $47 \%$ \\
\hline & Wanita & 111 & $53 \%$ \\
\hline \multirow{2}{*}{ Status Pernikahan } & Menikah & 61 & $29 \%$ \\
\hline & Tidak Menikah & 148 & $71 \%$ \\
\hline \multirow{5}{*}{ Pekerjaan } & Karyawan/PNS & 122 & $58 \%$ \\
\hline & Pelajar & 29 & $14 \%$ \\
\hline & Wiraswasta & 39 & $19 \%$ \\
\hline & Ibu Rumah Tangga & 18 & $9 \%$ \\
\hline & Dokter & 1 & $0 \%$ \\
\hline \multirow{4}{*}{ Tingkat Pendidikan } & SMA & 13 & $6 \%$ \\
\hline & D3 atau Setara & 7 & $3 \%$ \\
\hline & s1 & 156 & $75 \%$ \\
\hline & s2 & 33 & $16 \%$ \\
\hline \multirow{5}{*}{ Pendapatan Rata-Rata Per Bulan } & Kurang Dari 10 Juta & 129 & $62 \%$ \\
\hline & $10-20$ juta & 61 & $29 \%$ \\
\hline & $20-30$ juta & 12 & $6 \%$ \\
\hline & $30-40$ juta & 2 & $1 \%$ \\
\hline & Lebih dari 40 juta & 5 & $2 \%$ \\
\hline \multirow{7}{*}{ Domisili } & Jabodetabek & 141 & $67 \%$ \\
\hline & Bandung & 34 & $16 \%$ \\
\hline & Yogyakarta & 2 & $1 \%$ \\
\hline & Surabaya & 10 & $5 \%$ \\
\hline & Semarang & 2 & $1 \%$ \\
\hline & Makassar & 9 & $4 \%$ \\
\hline & Others & 11 & $5 \%$ \\
\hline
\end{tabular}

Tabel 2. Frekuensi Distribusi Karakteristik Perilaku

\begin{tabular}{|c|c|c|c|}
\hline \multicolumn{2}{|l|}{ Variabel } & \multirow{2}{*}{$\begin{array}{c}\text { Frekuensi } \\
59\end{array}$} & \multirow{2}{*}{$\begin{array}{c}\text { Persentase } \\
28 \%\end{array}$} \\
\hline Sebagian besar iklan online muncul & $\mathrm{Ya}$ & & \\
\hline untuk melihat iklan tersebut & Tidak & 150 & $72 \%$ \\
\hline \multirow{2}{*}{$\begin{array}{l}\text { Iklan online selalu memberikan } \\
\text { penawaran diskon atau voucher. }\end{array}$} & $\mathrm{Ya}$ & 80 & $38 \%$ \\
\hline & Tidak & 129 & $62 \%$ \\
\hline \multirow{2}{*}{$\begin{array}{l}\text { Saya berinteraksi secara intens dalam } \\
\text { aktifitas iklan online. }\end{array}$} & $\mathrm{Ya}$ & 20 & $10 \%$ \\
\hline & Tidak & 189 & $90 \%$ \\
\hline \multirow{2}{*}{$\begin{array}{l}\text { Saya sering memanfaatkan iklan } \\
\text { online untuk berbelanja. }\end{array}$} & Ya & 49 & $23 \%$ \\
\hline & Tidak & 160 & $77 \%$ \\
\hline \multirow{3}{*}{$\begin{array}{l}\text { Kapan waktu yang tepat bagi Anda } \\
\text { untuk menerima iklan online? }\end{array}$} & Pagi hari & 30 & $14 \%$ \\
\hline & Siang hari & 51 & $24 \%$ \\
\hline & Malam hari & 128 & $61 \%$ \\
\hline \multirow{4}{*}{$\begin{array}{l}\text { Seberapa sering Anda bersedia } \\
\text { menerima iklan online dalam sehari? }\end{array}$} & Kurang Dari 1 kali sehari & 102 & $49 \%$ \\
\hline & 2 kali sehari & 54 & $26 \%$ \\
\hline & 3 kali sehari & 17 & $8 \%$ \\
\hline & Lebih Dari 3 kali sehari & 36 & $17 \%$ \\
\hline
\end{tabular}

\section{Analisa Data}

Pada Tabel 1, dapat dilihat bahwa total responden mencapai 209 responden yang terdiri dari 98 responden pria (47\%) dan 111 responden wanita (53\%) dengan rentang usia 17-27 tahun sebanyak 99 responden (47\%), dan usia 28-37 tahun sebanyak 110 responden (53\%). Rentang usia ini sudah sesuai dengan target penelitian dalam jurnal ini yaitu menyasar pada Generasi Millennial yang berada dalam rentang usia 17-37 tahun. Dimana rentang usia ini adalah rentang usia produktif dan memiliki kontribusi terhadap peningkatan perekonomian Indonesia. Data demografi dari hasil survei yang dilakukan menunjukan bahwa responden memiliki tingkat pendidikan yang cukup tinggi, dimana lebih dari 90\% merupakan lulusan S1 dan S2, dengan 58\% responden merupakan karyawan/PNS, lebih dari 19\% berprofesi sebagai wiraswasta dan sisanya merupakan pelajar, ibu rumah tangga dan dokter.

Hasil survei yang ditunjukan oleh Tabel 2 menunjukan bahwa mayoritas iklan online (72\%) muncul tanpa meminta persetujuan dari konsumen, hal itu menunjukan bahwa perusahaan merasa bahwa meminta persetujuan dari konsumen bukanlah hal yang efektif agar konsumen mau melihat atau membuka iklan online mereka. Hasil survei juga menunjukan bahwa mayoritas perusahaan tidak memberikan penawaran diskon atau voucher dalam iklan online mereka, hal ini ditunjukan dari survei responden menjawab tidak menerima penawaran diskon/voucher yang mencapai 62\%. Di sisi lain, mayoritas responden tidak merasa sering memanfaatkan iklan online untuk berbelanja (77\%) dan berinteraksi secara intens dalam aktifitas iklan online (90\%), hasil tersebut menunjukan tingkat keterlibatan konsumen terkait 
aktifitas dan dampak dari iklan online cukup rendah. Pada survei kali ini juga ditanyakan mengenai kapan dan seberapa sering responden bersedia menerima iklan online, dengan hasil yang didapat yaitu mayoritas responden bersedia menerima iklan online pada malam hari (61\%) dan kurang dari 1 kali sehari (49\%).

\section{Analisis Realibilitas}

Tabel 3. Reliability Statistics

\begin{tabular}{|c|c|c|}
\hline \multicolumn{3}{|c|}{ Reliability Statistics } \\
\hline & $\begin{array}{c}\text { Cronbach's } \\
\text { Alpha Based }\end{array}$ & \\
on & \\
Cronbach's & Standardized \\
Alpha & Items & Items \\
\hline .861 & .859 & 21 \\
\hline
\end{tabular}

Realibilitas adalah konsistensi dari suatu pengukuran dalam mengukur sesuatu, hal ini merupakan pengujian untuk memastikan bahwa hasil pengujian awal akan konsisten dengan hasil pengujian-pengujian berikutnya. Cronbach Alpha Test adalah suatu metode untuk mengukur tingkat konsistensi yang akan menunjukan realibilitas dari berbagai faktor yang ada pada kuesioner. Data pada kuesioner akan dianggap realiable apabila nilai Cronbach Alpha lebih dari 00.7. asil perhitungan dengan menggunakan SPSS pada Tabel 3 menunjukan bahwa nilai Cronbach Alpha mencapai nilai 0.861, oleh karena itu dapat disimpulkan bahwa data kuesioner cukup realiable dan dapat digunakan untuk analisa data berikutnya.

\section{Statistik Deskriptif}

Dari hasil kuesioner, peneliti mendapatkan responden sebanyak 209 yang seluruhnya merupakan generasi millennial. Kuesioner tersebut memiliki skala 1 yang menunjukan sangat tidak setuju sampai skala 7 yang menunjukan sangat setuju. Hasil kuesioner pada Tabel 4 menunjukan nilai rata-rata yang berkisar mulai dari 2.6651 sampai 5.7033 dan standar deviasi yang berkisar dari 1.17590 sampai 1.58616, hal ini menunjukkan beragam respons konsumen terkait aktivitas iklan online.

\section{Descriptive Statistics}

\begin{tabular}{|l|r|r|r|}
\hline & Mean & $\begin{array}{c}\text { Std. } \\
\text { Deviati } \\
\text { on }\end{array}$ & $\begin{array}{c}\text { Analy } \\
\text { sis N }\end{array}$ \\
\hline $\begin{array}{l}\text { Merasa bahwa menerima iklan online itu menyenangkan dan } \\
\text { menghibur. }\end{array}$ & 2.9617 & 1.4406 \\
Merasa puas dalam menerima iklan online. & 2.9234 & 1.3636 & 209 \\
\hline
\end{tabular}


Melihat bahwa media hiburan (video, game, gambar) adalah suatu hal yang positif.

Merasa bahwa bentuk desain iklan online dapat bermacammacam.

Merasa bahwa iklan online adalah sumber yang tepat untuk mendapatkan informasi yang cepat.

Iklan online selalu memberikan informasi yang dibutuhkan.

Iklan online selalu membantu untuk mengetahui produk atau layanan terkini.

Menerima informasi yang berharga dari iklan online melalui ponsel.

Merasa bahwa iklan online menjengkelkan.

Merasa bahwa iklan online ada hampir di semua tempat.

Merasa nyaman dengan menerima pesan iklan di ponsel.

Isi iklan online sering mengganggu.

Menggunakan iklan online sebagai referensi untuk berbelanja.

Konten yang disediakan oleh iklan online dapat dipercaya.

Terkesan dengan iklan online.

Tidak dapat dipungkiri bahwa ponsel akan menjadi alat periklanan di masa depan.

Menerima pesan iklan online jika diberi insentif (seperti kupon diskon atau voucher belanja).

Terkesan jika iklan online memberikan insentif(seperti kupon diskon atau voucher belanja).

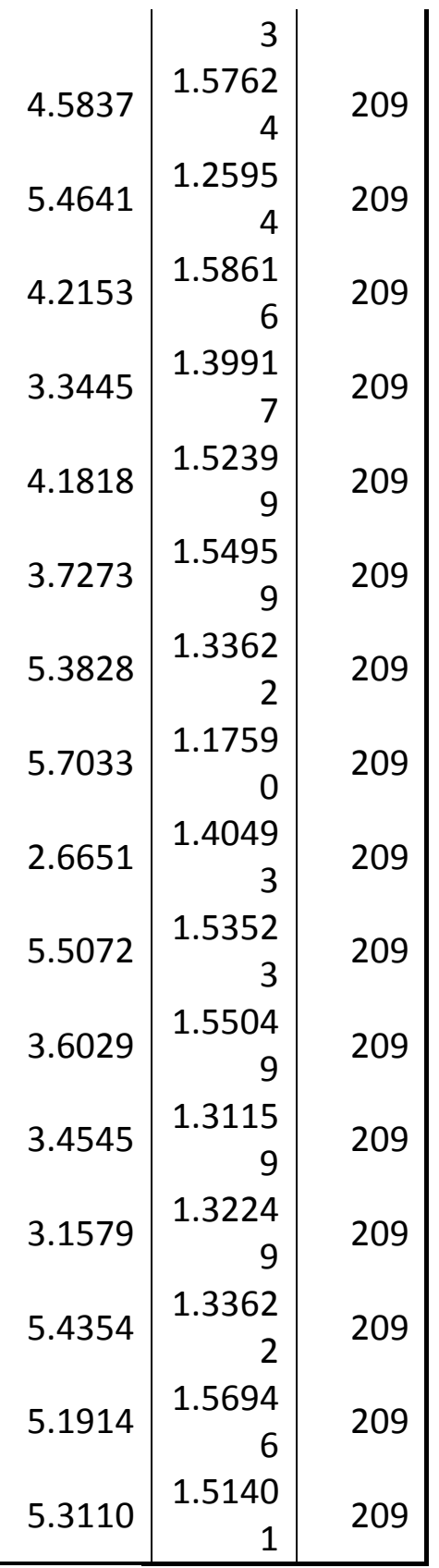

Tabel 4. Gambaran Statistika

\section{Faktor Analisis}

Tabel 5. KMO \& Bartlett's Test

KMO and Bartlett's Test

\begin{tabular}{|l|l|}
\hline Kaiser-Meyer-Olkin & \\
Measure of Sampling & .863 \\
Adequacy. & \\
\hline
\end{tabular}




\begin{tabular}{|ll|r|} 
Bartlett's & Approx. Chi- & 2050.841 \\
Test of & Square & 153 \\
Sphericity & df & 0.000 \\
& Sig.
\end{tabular}

Sebelum faktor analisa dilakukan, perlu dilakukan tes yang menunjukan bahwa data sampling mencukupi studi lebih lanjut. Metode tes tersebut adalah Kaiser-Meyer Olkin (KMO) dan Bartlett's Test. Nilai rujukan dari metode Kaiser-Meyer-Olkin adalah dalam rentang $0 \mathrm{~s} / \mathrm{d} 1$, sedangkan nilai rujukan dari Bartlett's test adalah $p<0.05$. Hasil dari perhitungan dalam Tabel 5 menunjukan hasil nilai KMO sebesar 0.863 dan Bartlett's test of sphericity sebesar 0,000 yang berarti data sampling sudah mencukupi untuk dilakukannya faktor analisis.

Communalities memiliki arti besarnya persentase dari variabel terhadap komponen yang terbentuk. Persentase variabel terhadap komponen yang terbentuk dianggap cukup signifikan apabila lebih dari 50\%. Dari hasil SPSS untuk 18 variabel, seluruh variabel memiliki persentase lebih dari 50\% kecuali variabel kepercayaan terhadap konten dalam iklan online, maka variabel tersebut dikeluarkan dan dilakukan kembali perhitungan melalui SPSS tanpa mengikutsertakan variabel tersebut. Maka diperoleh hasil communalities sesuai Tabel 6, dimana seluruh variabel memiliki persentase di atas $50 \%$.

\section{Tabel 6. Communalities}

\section{Communalities}

\begin{tabular}{|l|r|r|}
\hline & Initial & Extraction \\
\hline Merasa bahwa menerima iklan online itu menyenangkan dan menghibur. & 1.000 & .665 \\
Merasa puas dalam menerima iklan online. & 1.000 & .686 \\
Melihat bahwa media hiburan (video, game, gambar) adalah suatu hal & 1.000 & .570 \\
yang positif. & 1.000 & .764 \\
Merasa bahwa bentuk desain iklan online dapat bermacam-macam. & & \\
Merasa bahwa iklan online adalah sumber yang tepat untuk & 1.000 & .685 \\
mendapatkan informasi yang cepat. & 1.000 & .679 \\
Iklan online selalu memberikan informasi yang dibutuhkan. & \\
Iklan online selalu membantu untuk mengetahui produk atau layanan & 1.000 & .701 \\
terkini. & 1.000 & .589 \\
Menerima informasi yang berharga dari iklan online melalui ponsel. & 1.000 & .596 \\
Merasa bahwa iklan online menjengkelkan. & 1.000 & .678 \\
Merasa bahwa iklan online ada hampir di semua tempat. & 1.000 & .617 \\
Merasa nyaman dengan menerima pesan iklan di ponsel. & 1.000 & .615 \\
Isi iklan online sering mengganggu. & 1.000 & .679 \\
Menggunakan iklan online sebagai referensi untuk berbelanja. & 1.000 & .625 \\
Terkesan dengan iklan online. &
\end{tabular}


\begin{tabular}{|l|r|r|} 
Tidak dapat dipungkiri bahwa ponsel akan menjadi alat periklanan di & 1.000 & .508 \\
masa depan. & & .918 \\
$\begin{array}{l}\text { Menerima pesan iklan online jika diberi insentif (seperti kupon diskon } \\
\text { atau voucher belanja). }\end{array}$ & 1.000 \\
$\begin{array}{l}\text { Terkesan jika iklan online memberikan insentif(seperti kupon diskon atau } \\
\text { voucher belanja). }\end{array}$ & 1.000 & .897 \\
\hline
\end{tabular}

Extraction Method: Principal Component Analysis.

Figur 2. Screen Plot

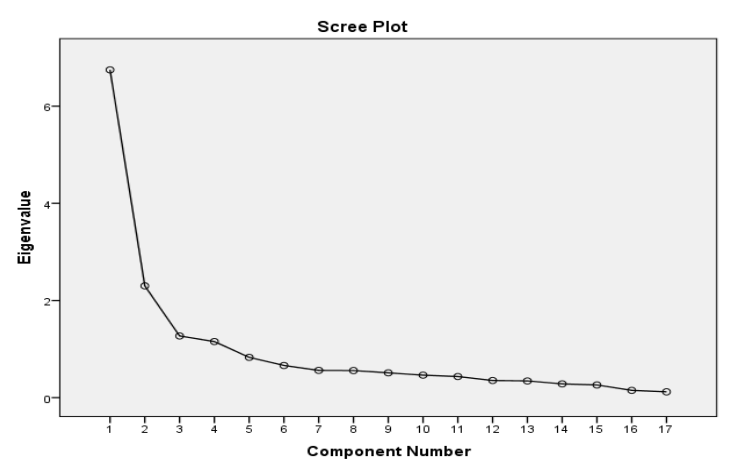

Beberapa studi memisahkan beberapa faktor dalam screen plot yang memiliki lebih dari 1 Eigen values. Pada Figur 2 yang menampilan screen plot, terdapat 4 faktor yang memiliki niliai Eigen values diatas 1. Maka studi ini dapat dibagi menjadi 4 faktor komponen.

Tabel 7. Total Variance Explained

Total Variance Explained

\begin{tabular}{|c|c|c|c|c|c|c|c|c|c|}
\hline \multirow{2}{*}{$\begin{array}{l}\text { Compon } \\
\text { ent }\end{array}$} & \multicolumn{3}{|c|}{ Initial Eigenvalues } & \multicolumn{3}{|c|}{$\begin{array}{l}\text { Extraction Sums of } \\
\text { Squared Loadings }\end{array}$} & \multicolumn{3}{|c|}{$\begin{array}{l}\text { Rotation Sums of } \\
\text { Squared Loadings }\end{array}$} \\
\hline & $\begin{array}{c}\text { Tota } \\
1\end{array}$ & $\begin{array}{c}\% \text { of } \\
\text { Varian } \\
\text { ce }\end{array}$ & $\begin{array}{l}\text { Cumulat } \\
\text { ive } \%\end{array}$ & $\begin{array}{l}\text { Tot } \\
\text { al }\end{array}$ & $\begin{array}{c}\% \text { of } \\
\text { Varian } \\
\text { ce }\end{array}$ & $\begin{array}{l}\text { Cumulat } \\
\text { ive } \%\end{array}$ & $\begin{array}{l}\text { Tot } \\
\text { al }\end{array}$ & $\begin{array}{c}\% \text { of } \\
\text { Varian } \\
\text { ce }\end{array}$ & $\begin{array}{c}\text { Cumulat } \\
\text { ive } \%\end{array}$ \\
\hline 1 & $\begin{array}{r}6.74 \\
7\end{array}$ & 39.689 & 39.689 & $\begin{array}{r}6.7 \\
47\end{array}$ & 39.689 & 39.689 & $\begin{array}{r}5.8 \\
66\end{array}$ & 34.503 & 34.503 \\
\hline 2 & $\begin{array}{r}2.30 \\
0\end{array}$ & 13.531 & 53.221 & $\begin{array}{r}2.3 \\
00\end{array}$ & 13.531 & 53.221 & $\begin{array}{r}1.9 \\
49\end{array}$ & 11.466 & 45.970 \\
\hline 3 & $\begin{array}{r}1.26 \\
9\end{array}$ & 7.467 & 60.688 & $\begin{array}{r}1.2 \\
69\end{array}$ & 7.467 & 60.688 & $\begin{array}{r}1.8 \\
34\end{array}$ & 10.787 & 56.756 \\
\hline 4 & $\begin{array}{r}1.15 \\
5\end{array}$ & 6.794 & 67.482 & $\begin{array}{r}1.1 \\
55\end{array}$ & 6.794 & 67.482 & $\begin{array}{r}1.8 \\
23\end{array}$ & 10.726 & 67.482 \\
\hline 5 & .829 & 4.879 & 72.361 & & & & & & \\
\hline 6 & .662 & 3.895 & 76.256 & & & & & & \\
\hline 7 & .561 & 3.302 & 79.558 & & & & & & \\
\hline 8 & .558 & 3.281 & 82.839 & & & & & & \\
\hline 9 & .510 & 3.002 & 85.841 & & & & & & \\
\hline 10 & .462 & 2.720 & 88.561 & & & & & & \\
\hline 11 & .434 & 2.555 & 91.117 & & & & & & \\
\hline 12 & .353 & 2.077 & 93.194 & & & & & & \\
\hline
\end{tabular}




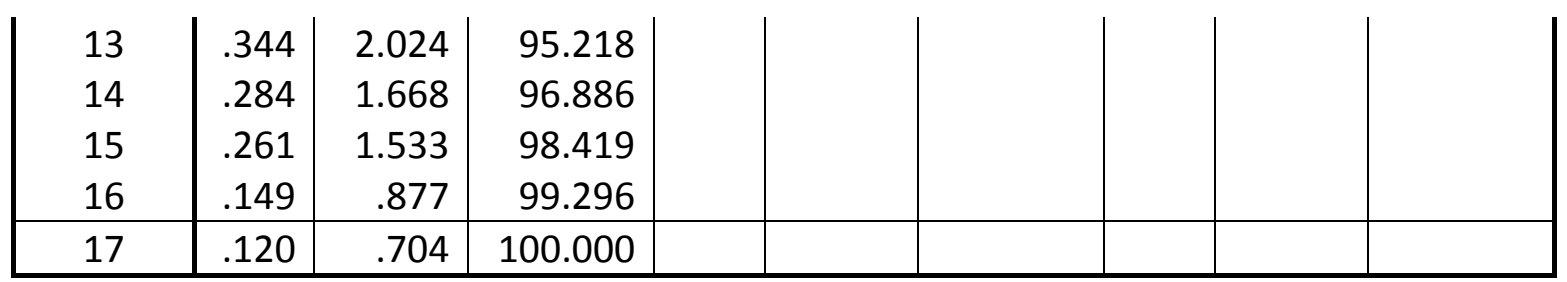

Extraction Method: Principal Component Analysis.

Tabel 7 Total Variance Explained menunjukan total variance dari beberapa komponen. Komponen-kompenen tersebut merupakan komponen utama yang memiliki nilai Eigen value diatas 1. Tabel tersebut menunjukan bahwa 4 komponen tersebut memiliki nilai Eigen value lebih dari 1 dengan persentasi kumulatif sebesar $67.842 \%$ dari total Varimax rotation for the rotated component matrix. Metodologi ini membantu meminimalisir jumlah variabel yang memiliki nilai lebih untuk setiap faktor dan menyediakan faktor-faktor yang mendasari perilaku pelanggan Millennial Indonesia terhadap iklan online. Berdasarkan data tersebut, seluruh variabel dapat dikategorikan menjadi 4 komponen.

Tabel 8. Rotated Component Matrix

Rotated Component Matrix

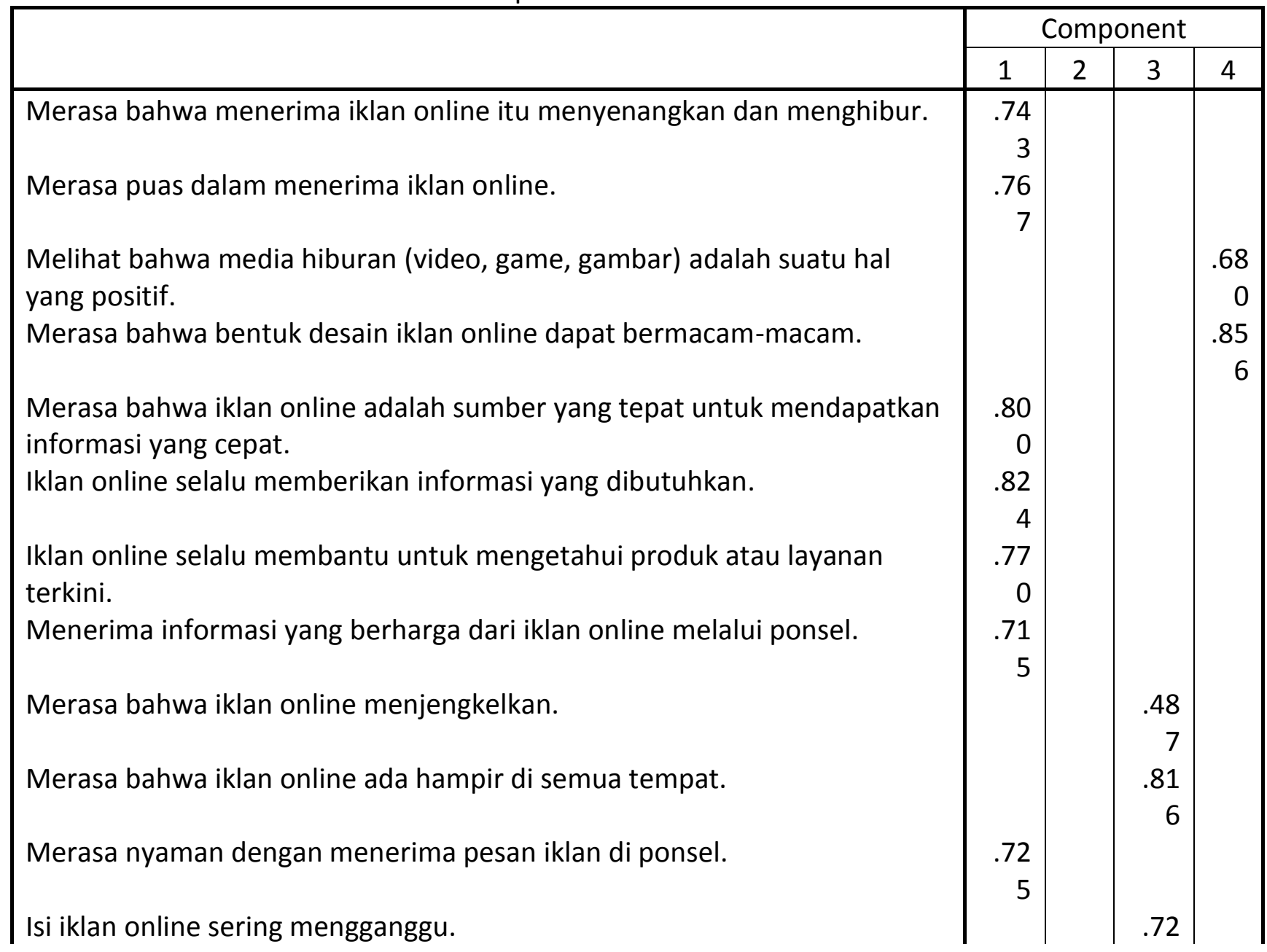


Menggunakan iklan online sebagai referensi untuk berbelanja.

Terkesan dengan iklan online.

Tidak dapat dipungkiri bahwa ponsel akan menjadi alat periklanan di masa depan.

Menerima pesan iklan online jika diberi insentif (seperti kupon diskon atau voucher belanja).

Terkesan jika iklan online memberikan insentif (seperti kupon diskon atau voucher belanja).

Extraction Method: Principal Component Analysis.

Rotation Method: Varimax with Kaiser Normalization.

a. Rotation converged in 6 iterations.

Berdasarkan Tabel 8 rotated component matrix di atas, 17 variabel dikelompokkan menjadi 4 komponen umum, yaitu:

Komponen 1: iklan online menyenangkan dan menghibur, kepuasan dalam menerima iklan online, iklan online adalah sumber yang tepat untuk mendapatkan informasi yang cepat, iklan online selalu memberikan informasi yang dibutuhkan, iklan online selalu membantu untuk mengetahui produk atau layanan terkini, memberikan informasi yang berharga dari iklan online melalui ponsel, kenyamanan dengan menerima pesan iklan di ponsel saya, iklan online sebagai referensi untuk berbelanja, konten yang disediakan oleh iklan online dapat dipercaya, terkesan dengan iklan online. Seluruh varibel ini dikategorikan sebagai komponen informativeness \& credibility.

Komponen 2: menerima pesan iklan online jika diberi incentive, terkesan jika iklan online memberikan incentive. Seluruh variabel ini dikategorikan sebagai komponen incentive.

Komponen 3: iklan online menjengkelkan, iklan online ada hampir di semua tempat, iklan online sering mengganggu. Seluruh variabel ini dikategorikan sebagai komponen irritation.

Komponen 4: media hiburan (video, game, gambar) adalah suatu hal yang positif, bentuk desain iklan online dapat bermacam-macam, ponsel akan menjadi alat periklanan di masa depan. Seluruh variabel ini dikategorikan sebagai komponen entertainment.

\section{Analisa Regresi}

Tabel 9. Model Summarv Model Summary

\begin{tabular}{|c|c|c|c|c|}
\hline Model & $\mathrm{R}$ & $\mathrm{R}$ Square & $\begin{array}{c}\text { Adjusted R } \\
\text { Square }\end{array}$ & $\begin{array}{c}\text { Std. Error of } \\
\text { the Estimate }\end{array}$ \\
\hline 1 & $.680^{2}$ & .463 & .452 & .85942 \\
\hline
\end{tabular}

a. Predictors: (Constant), Entertainment, Irritation, Incentive,

Informativeness_and_Credibility

\begin{tabular}{|c|c|c|c|c|c|c|}
\hline & \multicolumn{6}{|c|}{ Coefficients ${ }^{a}$} \\
\hline \multicolumn{7}{|c|}{ ANOVA ${ }^{a}$} \\
\hline & & \begin{tabular}{|c|} 
Sum of \\
Squares \\
\end{tabular} & df & $\begin{array}{l}\text { Mean } \\
\text { Square }\end{array}$ & $\mathrm{F}$ & Sig. \\
\hline 1 & Regression & 129.852 & 4 & 32.463 & 43.952 & $.000^{\circ}$ \\
\hline & Residval & 150.675 & 204 & .739 & & \\
\hline & Total & 280.526 & 208 & & & \\
\hline
\end{tabular}

Tabel di samping menunjukan bahwa korelasi antara perilaku konsumen Millennial di Indonesia dengan faktor independent variabel seperti bonus atau incentive, informativeness, irritation, credibility dan, entertainment adalah sebesar $45.2 \%$ yang dapat diartikan masih ada 
beberapa faktor lain yang mempengaruhi perilaku konsumen millennial di Indonesia terhadap iklan online. Berdasarkan Analysis Of Variance (ANOVA) P-value (0.000) atau lebih kecil dari 0.05 , alternatif hipotesa yang diterima berada di angka tingkat kepercayaan sebesar $95 \%$. Hal ini menunjukkan bahwa faktor entertainment, informativeness, irritation, credibility, dan incentive dapat digambarkan sebagai bagian dari faktor yang mempengaruhi perilaku pelanggan Millennial Indonesia terhdap iklan online. Berdasarkan Tabel Coefficients dapat diindikasikan bahwa terdapat hubungan yang cukup signifikan antara faktor informativeness_credibility dan entertainment dengan sikap dari konsumen millennial Indonesia terhadap iklan online. Tabel ini juga menunjukkan bahwa hanya dua faktor tersebut yang sangat berpengaruh terhadap sikap konsumen millennial Indonesia terhadap iklan online, dikarenakan dari hasil tabel Coefficients diatas hanya dua faktor yaitu informativeness_credibility dan entertainment yang menunjukkan angka standar value sama dengan atau dibawah 0.05 .

\section{Tes Hipotesa}

Hipotesa 1: Faktor entertainment menjadi faktor yang menentukan sikap pelanggan Millennial Indonesia terhadap iklan online. Berdasarkan analisa hasil survei, menunjukkan bahwa entertainment menjadi faktor yang menentukan sikap pelanggan Millennial Indonesia, dibuktikan dengan nilai $P$-value dari faktor ini adalah 0.004 lebih kecil dari 0.05 .

Hipotesa 2 dan Hipotesa 4: Informativeness dan Credibility dari iklan online atau kualitas iklan menjadi faktor yang menentukan sikap pelanggan Millennial Indonesia terhadap iklan online. Informativeness dan Credibility merujuk pada hasil Rotated Component Matrix dimana pada komponen 4 terdapat variabel-variabel dari pertanyaan mengenai informativeness dan credibility yang saling berkorelasi. Atau dapat dikatakan faktor informasi yang terkandung dalam iklan online tersebut merupakan cerminan kredibilitas perusahaan. Berdasarkan analisa hasil survei, menunjukkan bahwa kedua faktor ini menjadi faktor yang paling menentukan sikap perilaku pelanggan Millennial Indonesia, dibuktikan dengan nilai $P$-value dari faktor ini adalah 0.000 lebih kecil dari 0.05 .

Hipotesa 3: Faktor irritation dari iklan mempengaruhi sikap pelanggan Millennial Indonesia terhadap iklan online. Berdasarkan analisa hasil survei, menunjukkan bahwa menggangggunya (irritating) suatu iklan online tidak menentukan sikap pelanggan Millennial Indonesia atau netral, dibuktikan dengan nilai $P$-value dari faktor ini adalah 0.811 atau lebih besar dari 0.05 .

Hipotesa 5: Faktor incentive dari iklan online mempengaruhi sikap pelanggan Millennial Indonesia terhadap iklan online. Berdasarkan analisa hasil survei, menunjukkan bahwa pemberian incentive dari suatu iklan online terhadap pelanggan tidak menentukan sikap pelanggan Millennial Indonesia, dibuktikan dengan nilai $P$-value dari faktor ini adalah 0.508 lebih besar dari 0.05 .

\section{KESIMPULAN}

Pada kerangka konseptual penelitian, informativeness, entertainment dan credibility telah menunjukkan pengaruh positif dan signifikan langsung terhadap sikap konsumen akan 
iklan online. Berbagai faktor demografis yang bisa saja menjadi pengaruh mengapa hasil nya menjadi negatif, diantaranya perilaku pada usia responden (Generasi Millennial), lokasi sebaran responden, gaya hidup dan tingkat pendidikan ataupun lebih luasnya adalah budaya di Indonesia. Penelitian ini juga menemukan beberapa temuan seperti: waktu yang diharapkan untuk menerima iklan online adalah siang dan malam hari dan preferensi jumlah iklan yang ingin diterima pelanggan dalam sehari adalah kurang dari 3 (tiga) kali. Adapun limitasi dalam penelitian ini adalah keterbatasan waktu penelitian dan jumlah responden.

Faktor irritation dan incentive yang diprediksi mempengaruhi pengaruh signifikan memiliki nilai negatif. Hal ini menjadi menarik sebagai bahan dasar penelitian lanjutan, misalnya penambahan faktor independen untuk variable hipotesa penelitian, mengganti target penelitian pada rentang usia generasi $Z$, atau menspesifikan faktor demografis ruang lingkup penelitian.

Dari hasil penelitian sebagian besar Generasi Millennial yang merupakan target ideal untuk pertumbuhan profit ekonomi di Indonesia, menyukai iklan online dengan tingkat entertainment serta informativeness dan credibility yang tinggi. Oleh karena itu, perusahaan dapat menciptakan periklanan online dengan menggabungkan unsur-unsur hiburan, pengetahuan dan keyakinan untuk menarik dan mempertahankan perhatian konsumen. Meskipun temuan dalam penelitian ini menunjukkan bahwa faktor irritation dan incentive tidak signifikan terkait dengan sikap konsumen terhadap iklan online, namun tidak berarti perusahaan tersebut dapat mengabaikan kriteria ini dalam iklan mereka. Irritation dan incentive sebuah iklan online mungkin tidak berdampak pada sikap konsumen, namun dapat berdampak pada strategi marketing dan citra perusahaan.

Implikasi manajerial penelitian ini diharapkan membantu faktor pertimbangan untuk pemasar dalam merancang Integrated Marketing Communication (IMC) atau promotional mix yang menarik pelanggan. Konten, format dan struktur iklan harus akurat, menarik dan diterima oleh target penerima iklan online. 


\section{DAFTAR PUSTAKA}

Abdul Azeem \& Zia ul Haq. (2012). Perception towards internet advertising: a study with reference to three different demographic groups. Global Business and Management Research: An International Journal, from http://gbmr.ioksp.com/pdf/Azeem\%20and\%20Haq,\%202012.pdf (29 July 2017)

Annisa, F. (2017, May 4). Mengenal Indonesia Lewat Data : Generasi Millenial dan Terbukanya Peluang Ekonomi Baru Indonesia, from http://ideannisa.com/2017/05/04/peluang-ekonomibonus-demografi-millenial/ (25 July 2017)

Asosiasi Penyelenggara Jasa Internet Indonesia (2016). Statistik Pengguna dan Prilaku Pengguna Internet Indonesi. Retrieved from https://drive.google.com/file/d/OB2GX4iSFFEGqUmJHZkVteTVmcnc/view (29 July 2017)

Badan Pusat Stastistik (2013). Proyeksi Penduduk Indonesia 2010 - 2035, from https://www.bps.go.id/website/pdf publikasi/watermark Proyeksi\%20Penduduk\%20Indonesia \%202010-2035.pdf (29 July 2017)

Badan Pusat Statistik (2017). Statistik Indonesia, from https://www.bps.go.id/website/pdf_publikasi/Statistik-Indonesia-2017.pdf (29 July 2017)

Barton, C., Fromm, J. and Egan, C (2012). The Millennial Consumer Debunking Streotypes. Boston Consulting Group, from https://www.bcg.com/documents/file103894.pdf (25 July 2017)

Brackett, L. K. and Carr, B. N. "Cyberspace Advertising vs. Other Media: Consumer vs. Mature Student Attitudes." Journal of Advertising Research. (41:5), 2001, pp. 23-33.

Cascio, Wayne F., (1995). Managing Human Resources, Productivity, Quality of Work Life, Profit, fourth edition, Mc GrawHill.

Dewanto, T.N. (2017, Feb). Karakteristik Konsumen Generasi Digital, from https://tuhunugraha.com/digital-strategy/2017/01/25/karakteristik-konsumen-generasidigital/ (25 July 2017)

Dickinger, A., Haghirian, P., Murphy, J. dan Scharl, A. (2004), An Investigation And Conceptual Model Of SMS Marketing, from http://www.keyana.ae/wpcontent/up loads/An-InvestigationandConceptual -Model-of-SMS-Marketing.pdf 
Ducoffe, RH (1996). Advertising value and advertising on the web. J. Advertising Res. 36(5): 2135.

George, CG (2013, May 21). Online Advertising's Impact on Business, from https://blog.adstage.io/2013/03/21/online-advertising-impact (29 July 2017)

Goldmansachs Asset Management (2016, September) Investing in the Millenial Effect. Fundamental Equity, from https://www.gsam.com/content/dam/gsam/pdfs/common/en/public/articles/global-equityoutlook/investing-in-the-millennial-effect.pdf?sa=n\&rd=n (25 July 2017)

Goldmansach (2017) Millenials Coming Of Age, from http://www.goldmansachs.com/ourthinking/pages/millennials/(2 August 2017)

Goldsmith, R. E., Lafferty, B. A., \& Newell, S. J. (2000). The Impact of Corporate Credibility and Celebrity Credibility on Consumer Reaction to Advertisements and Brands. Journal of Advertising, Vol. 29(3), 43.

Gustari, I. (2017). Mencermati Teori Pengotakan Generasi. Riau Post (10 Februari 2017), from http://riaupos.co/5048-opini-mencermati-teori--pengotakangenerasi.htm|\#.WYB1trZLfIU\#ixzz4oVVFLKHT (25 July 2017)

Harsono (1987), Manajemen Publik Cetakan Kedua, Balai Aksara Ghalia Indonesia, 1987.

Isparmo (2016, November 21). Data Statistik Pengguna Internet Indonesia tahun 2016, from http://isparmo.web.id/2016/11/21/data-statistik-pengguna-internet-indonesia-2016/(2 August 2017)

Kementrian Komunikasi dan Informatika RI (2016). Komposisi pengguna internet berdasarkan umur, from https://statistik.kominfo.go.id/site/data?idtree=424\&iddoc $=1517$

Kotler, P., \& Armstrong, G. (2010). Principles of marketing. Pearson Education.

Kotler, P. and Keller, K. (2016). Marketing Management, 15th ed. Essex: Pearson Education Limited.

Le,T.D.,\&Nguyen,B.T.H.(2014).Attitudes toward mobile advertising: A study of mobile web display and mobile APP display advertising.

Luxton, S., Mahmood, U., \& Ferraro, C. (2009). Mobile phone marketing: challenges and perceived attitudes. In Australian and New Zealand Marketing Academy (ANZMAC) Conference 2009 (Mike Ewing and Felix Mavondo 30 November 2009 to 2 December 2009) (pp. 1-11). 
MacKenzie, S. B., \& Lutz, R. J. (1989). An empirical examination of the structural antecedents of attitude toward the ad in an advertising pretesting context. The Journal of Marketing, 48-65. Riyanto, A. (2016, April). Definisi Online Advertising dan keunggulannya, from http://estudy2016.blogspot.co.id/ (25 July 2017)

Rieh, S. Y. \& Danielson, D. R. (2007). Credibility: A multidisciplinary framework. In B. Cronin. (Ed.), Annual Review of Information Science and Technology, from htpp://rieh.people.si.umich.edu/ rieh/papers/rieh ARIST2007.pdf

Scharl, A., Dickinger, A., \& Murphy, J. (2005). Diffusion and success factors of mobile marketing. Electronic commerce research and applications, 4(2), 159-173.

Schiffman, L. G., Hansen, H., \& Kanuk, L. L. (2008). Consumer behaviour: A European outlook. Pearson Education

Sheikh Majedul Huq et al.(2015, Oct). Customer's Attitude Towards Mobile Advertising in Bangladesh.International Journal of Business and Economics Research 2015; 4(6): 281-292.

Simbolon, F. (2017, March 08). Mengenal Pemasaran Digital untuk Generasi Millenials, from http://bbs.binus.ac.id/international-marketing/2017/03/mengenal-pemasaran-digital-untukgenerasi-millenials/(25 July 2017)

Stokes, Rob (2013) e-Marketing the Essential Guide to Marketing in Digital World, 5th Edition, from https://www.redandyellow.co.za/wp-content/uploads/11-Online-Advertising QuirkTextbook-5.pdf (29 July 2017)

Tania, S. (2017). Advertising Values dan Perilaku Konsumen: Pengaruh Advertising Values dalam Tagged Promotion terhadap Perilaku Konsumen (Consumer Attitudes) Online Fashion Shop Facebook di Yogyakarta, from http://www.academia.edu/17618182/Advertising Values dan Perilaku Konsumen Pengaruh Advertising Values dalam Tagged Promotion terhadap Perilaku Konsumen Consumer Attit udes Online Fashion Shop Facebook di Yogyakarta (25 July 2017)

Tsang, M. M., Ho, S. C., \& Liang, T. P. (2004). Consumer attitudes toward mobile advertising: An empirical study. International Journal of Electronic Commerce, 8(3), 65-78.

Wikinvest.com (2012). Impact of Internet Advertising from http://www.wikinvest.com/concept/Impact of Internet Advertising (29 July 2017)

Yusuf, I. A. (2010, May 27). Mobile Advertising: Era Baru Beriklan, from https://bincangmedia.wordpress.com/2010/05/27/mobile-advertising-era-baruberiklan/\# ftn2 (2 August 2017) 